\title{
Holismo Metodológico Moderado: uma interpretação weberiana do modelo macro-micro-macro
}

Gert Albert ${ }^{2}$

\section{Resumo}

O artigo identifica uma clara e indiscutível tendência antirreducionista na sociologia weberiana que coloca em igual posição tanto o nível da ação quanto o nível da estrutura social. Com base nesse pressuposto sugere-se que um paradigma weberiano poderia ser designado como um holismo metodológico moderado. Essa posição combina uma ontologia holista restrita com o modelo explicativo macro-micro-macro. Com base nas atuais reflexões sobre emergência, distingue-se o holismo metodológico moderado de outras posições metodológicas, além de desenvolvê-lo adotando como modelo explicativo os estudos weberianos sobre a ética protestante e a tipologia da dominação. Em seguida demonstra-se que uma teoria da ação de tipo weberiano que adota o princípio "motivos como causa" possui uma orientação fundamentalmente holista que, consequentemente, não exclui da análise o nível da ordem social. Essa versão de um paradigma weberiano possui uma inclinação de base ontológica com uma sociologia de orientação histórica e empírica.

Palavras-chave: Max Weber. Macro. Micro. Individualismo metodológico. Holismo metodológico.

\section{Introdução}

Weber costuma ser convencionalmente apresentado como um representante do individualismo metodológico. Se levarmos em consideração suas declaraçóes oficiais sobre esse tema, isso não deixa de estar correto. Mas, junto a tais manifestaçôes, também podemos identificar em seus escritos uma clara tendência antireducionista. Como afirma Wolfgang Schluchter (2000a, p. 91), em contraste com Mead, em Weber não existe um primado lógico nem do indivíduo nem do processo social. Thomas Schwinn, da mesma

\footnotetext{
Tradução de Carlos Eduardo Sell.

2 Doutor e Livre Docente em Sociologia pela Universidade de Heidelberg e professor da Universidade das Forças Ar-madas (Munique). Coordenador da coleção "Estudos para um paradigma weberiano da VS Editora de Wiesbaden (Alemanha).
} 
forma, é da opinião de que Weber evita privilegiar o nível individual ou o nível estrutural em relação ao problema micro-macro, o que o transforma em um interessante parceiro nas discussóes atuais (SCHWINN, 1993, p. 235). M. Rainer Lepsius, partindo de Weber, chega a afirmar que é o conflito entre as instituiçóes que constitui o agente da história. Ele faz referência a famosa frase de Marx e Engels e lhe confere um novo sentido: "a história de todas as sociedades até hoje é a história das lutas entre as instituiçôes" (LEPSIUS, 1997, p. 392). Naturalmente, essa afirmaçáo náo reflete nenhuma concepçáo macrossociológica pura, pois ele logo acrescenta: "as instituiçôes operam sempre através de atores e estes se orientam por certas ideias" (idem, p. 399). Por fim, Stefan Breuer, em seu esforço de desenvolvimento da sociologia da dominação de Weber, chega a uma conclusão semelhante, pois ele mostra coma nos tipos de dominaçáo existe uma prioridade do nível da ordem em relação ao nível individual, na medida em que ele náo entende a dominaçáo racional como institucionalização da racionalidade de fins, mas, com certo tom durkheimiano, como "ordem sui generis" (BREUER, 1991, p. 194).

Tais afirmaçóes parecem convergir tendencialmente para a posição que Joseph Agassi, inspirado em Weber, formulou em seu famoso artigo de 1975 e que é chamada de "individualismo institucional" (ver também UDEHN, 2001, p. 218-221). No contexto do debate sobre individualismo e holismo, que envolveu autores como Watkins, Popper, Gellner e Mandelbaum; Joseph Agassi, representando a posição do racionalismo crítico, sustentou que: "ainda assim, tanto o indivíduo quanto a sociedade podem ser considerados como primários, ao menos no sentido de que não podemos reduzir a psicologia à sociologia, nem a sociologia à psicologia" (AGASSI, 1975, p. 152). O individualismo institucional de Agassi é uma tentativa de combinar o holismo com o individualismo e é por isso, em contraste com o ponto de vista macrossociológico radical, que podemos falar de um holismo moderado.

Nesse artigo, inspirando-me também em Weber, busco desenvolver uma interpretação holista-moderada do modelo macro-micro-macro. De que modo essa interpretaçáo se diferencia daquela elaborada pelo individualismo metodológico da escolha racional? Para responder a essa pergunta procederei da seguinte forma. Primeiramente, partindo das atuais discussóes teóricas no campo da filosofia, esclareço a relação entre emergência e explicação causal. Tomando essa discussão como pano de fundo, diferencio quatro posiçóes sociológicas: 1) individualismo metodológico radical, 2) individualismo metodológico moderado 3 , 3) holismo metodológico radical e, por fim, o 4) holismo

3 A distinção que Michael Schmid (1996, p. 63 e SS.) faz entre uma versão mais e outra menos radical do individualismo metodológico converge com minha diferenciação entre uma versão radical e outra moderada. 
metodológico moderado, a posição que defenderei aqui. Após, procuro mostrar como os estudos de Weber sobre a ética protestante, bem como sua sociologia da dominaçáo, podem ser compreendidos como modelos de uma explicação sociológica de tipo holista, ainda que, é claro, moderada. A seguir retomo a teoria weberiana da ação na perspectiva explicativo-compreensiva e, a partir daí, formulo um argumento antireducionista. A conclusão pode ser lida como a defesa de um paradigma weberiano entendido como um holismo metodológico de tipo moderado (sobre o paradigma weberiano ver Albert (2003) e Schluchter (2003 e 2005)).

\section{Emergência e explicação causal}

O holismo metodológico moderado compartilha com o individualismo metodológico o modelo macro-micro-macro de explicação sociológica, mas lhe confere uma interpretação diferente. Do holismo metodológico radical (ou coletivismo) ele adota o pressuposto da emergência, mas, em contraste com ele, assume uma posição individualista, baseada na teoria da ação, ou seja, ele rejeita uma macrossociologia pura. Para esclarecer melhor essa posição apresento quatro pontos de vista metodológicos que podem ser encontrados atualmente na sociologia ${ }^{4}$ :

\section{Quadro 1}

Critérios de Distinção de Quatro Posições Metodológicas

\begin{tabular}{|l|l|l|l|l|}
\hline & $\begin{array}{l}\text { Holismo } \\
\text { Radical }\end{array}$ & $\begin{array}{l}\text { Individualismo } \\
\text { Radical }\end{array}$ & $\begin{array}{l}\text { Individualismo } \\
\text { Moderado }\end{array}$ & $\begin{array}{l}\text { Holismo } \\
\text { Moderado }\end{array}$ \\
\hline Emergencia & Forte & Inexistente & Fraco & Fraco e forte \\
\hline Causalidade & $\begin{array}{l}\text { Same-level } \\
\text { causation } \\
\text { (macro) }\end{array}$ & $\begin{array}{l}\text { Same-level causa- } \\
\text { tion } \\
\text { (micro) }\end{array}$ & $\begin{array}{l}\text { Apenas uproard } \\
\text { causation (ma- } \\
\text { cro-micro-ma- } \\
\text { cro) }\end{array}$ & $\begin{array}{l}\text { Também doton- } \\
\text { card } \\
\text { causation (ma- } \\
\text { cro-micro-ma- } \\
\text { cro) }\end{array}$ \\
\hline $\begin{array}{l}\text { Relação } \\
\text { Micro-Macro }\end{array}$ & $\begin{array}{l}\text { Fusão do micro } \\
\text { no plano macro }\end{array}$ & $\begin{array}{l}\text { Proposiçôes } \\
\text { analíticas }\end{array}$ & $\begin{array}{l}\text { Explicaçôes for- } \\
\text { tes }\end{array}$ & $\begin{array}{l}\text { Explicaçôes fra- } \\
\text { cas }\end{array}$ \\
\hline $\begin{array}{l}\text { Modelo Expll- } \\
\text { cativo }\end{array}$ & Macro-macro & $\begin{array}{l}\text { "Macro"-micro- } \\
\text { "macro" }\end{array}$ & $\begin{array}{l}\text { Macro-mi- } \\
\text { cro-macro }\end{array}$ & $\begin{array}{l}\text { Macro-mi- } \\
\text { cro-macro }\end{array}$ \\
\hline
\end{tabular}

Fonte: Albert (2005:389).

40 mesmo procedimento, mas com conclusões completamente diversas, é adotado por Bettina Heinz (2004). 
Essas quatro posiçóes podem ser diferenciadas a depender dos seguintes fatores: 1) Se em relação ao nível macro elas reconhecem propriedades emergentes ou, ao contrário, se elas defendem uma posição eliminativa (teoria da identidade) e, no primeiro caso, se as propriedades emergentes são fortes ou fracas; 2) Se elas admitem apenas a causalidade ascendente (upward causation ou micro-determinação) ou também a causalidade descendente (downward-causation ou macrodeterminação); 3) Se a relação micro-macro (chamada por Esser de lógica da agregação) é concebida como uma questão de definição que requer apenas juízos analíticos ou se ela é concebida como um problema explicativo que requer juízos sintéticos e, caso se admita a última solução, se elas esclarecem os fenômenos de nível macro com explicaçóes fortes ou fracas. Esses três pontos estão em estreita relação sistemática.

Antes de caracterizar individualmente cada uma dessas quatro posiçóes, gostaria de me remeter, ainda que muito rapidamente, ao conceito de emergência e a suas implicaçóes teóricas em relação ao tema da explicação causal. Nesse ponto retomo os importantes trabalhos de Achim Stephan (2002) e de Paulo Hoyningen-Huene (1994) sobre o problema a emergência e os estudos de Robert Commins (1985) sobre instâncias explicativas.

\section{Emergência forte ou fraca}

Teorias da emergência possuem um ponto de partida naturalista (STHEPAN, 2002). Elas procuram respeitar o caráter específico dos fenômenos naturais na medida em que a explicação para o surgimento e existência de fenômenos como "espírito", "vida" ou o "social" fundamentam-se sempre em certas configuraçóes de elementos materiais. A atual história da ciência baseia-se na tese de que, a princípio, existia apenas a matéria e que, em determinado momento da evoluçáo, a partir de complexas combinaçóes de seus elementos, surgiram ou emergiram novas propriedades. Teorias da emergência implicam, portanto, um materialismo não-reducionista que exclui tanto posiçóes vitalistas quanto substancial-dualistas (STHEPAN, 2002, p. 125). Teorias da emergência, sejam elas fortes ou fracas ${ }^{5}$, possuem três pressupostos em comum e diferenciam-se em relaçáo a uma quarta (STHEPAN, 2002, p. 124-140).

5 Limitar-me-ei apenas a distinção entre emergência forte e fraca, deixando outras possibilidades de lado. 
O primeiro desses pressupostos é o monismo físico: todos os componentes do sistema que geram as propriedades emergentes possuem uma natureza física ou material. Em última instância, o que esse pressuposto descreve são os fundamentos naturalistas da teoria da emergência. $\mathrm{O}$ segundo pressuposto trata das propriedades sistêmicas. Apenas propriedades sistêmicas possuem uma natureza emergente ou, dito de outra forma, as propriedades são sistêmicas quando o sistema produz as propriedades, mas náo os componentes do sistema. Um exemplo disso é a capacidade de respirar ou, no campo do social, "o fato de que a continuidade da sociedade é mais longa que a do indivíduo". O terceiro pressuposto é a determinação sincrônica que diz respeito à relação entre os elementos micro e as estruturas macro. Determinação sincrônica significa que não podem ocorrer mudanças nas propriedades sistêmicas sem que as configuraçôes ou as características dos componentes sistêmicos também se alterem (se entendemos as mudanças de configuração como variaçóes micro). Portanto, não existe macrovariação sem microvariação, embora possam existir micro-variaçóes sem macrovariaçóes. Esse último caso significa a possibilidade de que possam ocorrer mudanças nos elementos micro ou em sua configuração que não provocam mudanças no nível macro.

Estes três pressupostos são compartilhados pelo conjunto das teorias da emergência, mas existe um ponto na qual elas divergem: se as propriedades emergentes devem ser consideradas "fortes" ou "fracas". A distinção entre emergência de tipo fraco ou de tipo fraco resulta do critério da "redutibilidade" ou da "irredutibilidade" (HOYNINGEN-HUME). Propriedades emergentes fortes são irredutíveis e as de tipo fraco são redutíveis. Para entendermos a natureza da redução ou da irredutibilidade, por sua vez, temos que esclarecer que modelo explicativo está sendo empregado, ou seja, temos que verificar se este modelo admite propriedades sistêmicas fortes ou fracas: fenômenos emergentes fortes requerem explicaçóes fracas e são, portanto, irredutíveis; já fenômenos emergentes fracos podem ser compreendidos somente por meio de explicaçóes reducionistas, ou seja, fortes ${ }^{6}$. É o que vamos esclarecer a seguir.

6 O que eu faço é combinar o conceito de emergência em sua forma usual, tal como ele foi explicitado por Stephan, com os conceitos de explicação forte ou fraca que foram elaboradas por Robert Commins (1985) e que ganharam sua atual denominação com Beckermann (1996). Mas, tais explicações têm um caráter mereológico e não causal. Trata-se, pois, da relação entre a parte e o todo. 


\section{Explicações fortes ou fracas}

Uma explicação fraca possui a forma de uma explicação nomológico-dedutiva (CUMMINS, 1985; BECKERMANN, 1996, p. 6). A variável dependente (explanandum) é a existência de um fenômeno emergente. Na variável independente (explanans) encontramos dois elementos. Em primeiro lugar, uma lei científica que descreve as propriedades do fator constituinte, ou seja, os componentes micro do sistema e suas configuraçóes como um antecedente (condição: "se"), bem como as propriedades do sistema como um consequente (consequência: "entáo"). Além do antecedente e do consequente, temos, em segundo lugar, as condiçóes iniciais que estabelecem se as condiçóes antecedentes realmente estáo presentes:

Lei 1: para todo $X$ vale que: quando $X$ consiste em partes de A1... An, que estáo organizados conforme $\mathrm{O}$, ou seja, quando $\mathrm{X}$ possui a estrutura [A1...An; O], entáo $\mathrm{X}$ tem a propriedade $\mathrm{P}$.

Condiçóes iniciais: $\mathrm{X}$ tem a estrutura $[\mathrm{A} 1, \ldots . ., \mathrm{An}, \mathrm{O}]$.

Explanandum: $\mathrm{X}$ tem a propriedade $\mathrm{P}$.

Esse esquema pode ser utilizado pelo modelo macro-micro para explicar fenômenos emergentes fortes ${ }^{7}$. No entanto, fenômenos emergentes fortes podem até ser explicados de modo nomológico-dedutivo, mas é importante lembrar que eles não podem ser prognosticados antes de sua primeira ocorrência. Somente a ocorrência inicial de fenômenos emergentes fortes é que funda a possibilidade de encontrar explicaçóes e leis para eles. No caso de fenômenos emergentes fracos a situação é outra. Se as propriedades nomológicas dos componentes micro do sistema estiveram esclarecidas, podemos, através da descriçáo empírica do modo como eles estáo combinados, deduzir suas propriedades emergentes. Por isso, no caso dos fenômenos emergentes fracos, é valida a chamada lei da instanciação (Lei 2) que postula que as propriedades emergentes são dependentes das micro-estruturas do sistema, ou seja, podem

7 Explicações fortes ou fracas desse tipo tem um caráter mereológico, mas não causal. Trata-se da ordenação de partes que compõem uma totalidade (BALOG, 1993). 
ser deduzidas dos atributos ou das propriedades nomológicas ${ }^{8}$ dos componentes micro (CUMMINS, 1985, p.18). Esses atributos nomológicos podem ser formulados da seguinte maneira:

Lei 2: As características de A1... An existem "aconteça o que acontecer".

As propriedades nomológicas são, dessa forma, proposiçóes fundamentais pelas quais as propriedades emergentes são entendidas como o resultado de certas disposiçóes organizacionais presentes no nível sistêmico. Portanto, para deduzir os princípios de instanciação dos atributos nomológicos necessita-se, primeiramente, conhecer o estado organizacional dos microcomponentes que compóem o sistema. Isso significa que devemos, inicialmente, ter visto como, em um sistema qualquer, a organizaçáo dos seus microcomponentes opera. Uma vez que tenhamos compreendido o princípio organizacional dos componentes micro, teremos compreendido o conjunto do sistema em todas as suas situaçóes ou possibilidades. É dessa forma que podemos compreender o postulado da irredutibilidade de Stephan que, passando por Broad, afirma que: "uma propriedade sistêmica (P) de um sistema (S) é irredutível quando, ainda que os elementos que fazem parte desse Sistema (S) apresentem uma combinação distinta da anterior, não se pode prever o comportamento do Sistema (S) como um todo" (STEPHAN, 2002, p. 131) ${ }^{9}$.

Isso tem como implicação a chamada causalidade descendente, ou "downward causation" (STEPHAN, 2002, p. 131) ${ }^{10}$. Quando o comportamento dos componentes do sistema, a depender de sua disposição - quer dizer, de acordo com sua estrutura - sofre variaçóes, isso significa que o "todo" (a estrutura do sistema) exerce influência sobre seus componentes. Logo, a emergência forte

8 Leis que, sem exceção, valem para todos os microcomponentes de um sistema, são chamadas por Cummins de atributos nomológicos (CUMMINS, 1985, p. 18).

9 A primeira condição de reduzibilidade aduzida por Achim Stephan não me parece aplicável ao caso da sociologia. Ela é apenas um argumento especial para o problema dos qualia na filosofia da psicologia (STEPHAN, 2002, p. 131.).

10 Podem existir também fenômenos emergentes que são apenas epifenômenos, ou seja, que não exercem poder causal. Não trataremos disso aqui, mas no caso da correção dessas condições de reduzibilidade, não se tratam de epifenômenos. 
está sempre relacionada com a causalidade descendente e é acompanhada, no que diz respeito a relação micro-macro, de explicações fracas. A emergência fraca está sempre relacionada com a causalidade ascendente e só pode ser compreendida, no tocante a relação micro-macro, mediante explicaçóes fortes.

\section{Quatro posições metodológicas}

Com base nesses conceitos podemos caracterizar quatro posiçóes metodológicas existentes na sociologia.

\section{Individualismo metodológico moderado}

O individualismo metodológico moderado admite a existência de propriedades emergentes no nível sistêmico, porém, ela as enxerga apenas como epifenômenos e, por essa razão, não lhes atribui nenhum tipo de influência causal sobre os componentes sistêmicos ${ }^{\prime \prime}$. O objeto da explicação (epifenômenos) é, portanto, localizado no nível macro. Na teoria da escolha racional, a relação macro-micro consiste de "incentivos" (Lógica da situação), sejam elas oportunidades ou restriçóes, que nos são fornecidas pelas instituiçóes vigentes. No entanto, o discurso sobre a influência das instituiçóes é pensada apenas metaforicamente: na verdade, não se postulam efeitos causais reais, pois, em última instância, a única coisa que realmente existe são os efeitos gerados pelas açóes dos indivíduos que, uma vez realizadas, produzem aquilo que chamamos de nível macro. Por isso, na apresentaçáo do modelo macro-micro de explicação, vemos as linhas apontando sempre na direçáo superior do gráfico, dado que elas devem ser interpretadas sempre em sentido causal. Linhas com a direção descendente, como no caso relação macro-micro, já que não possuem existência real e também não exercem nenhum tipo de efeito causal, devem ser apresentadas de forma pontilhada. Já a relação micro-macro deve ser representada com uma linha contínua para caracterizar a microdeterminaçáo e a causalidade ascendente e para que os fenômenos de nível macro possam ser compreendidos como resultado de explicaçóes fortes:

11 Godehard Brüntrüp nos fornece um interessante argumento contra o pressuposto da epifenomenalidade: "a existência de tais epifenômenos seria um mistério já que eles não exercem qualquer efeito e, por isso, não há qualquer motivo evolutivo para seu surgimento e evolução. E mais: se eles não possuem qualquer efeito retroativo sobre o mundo então há que se perguntar como poderíamos conhecê-los, já que eles simplesmente não deixam pistas". 

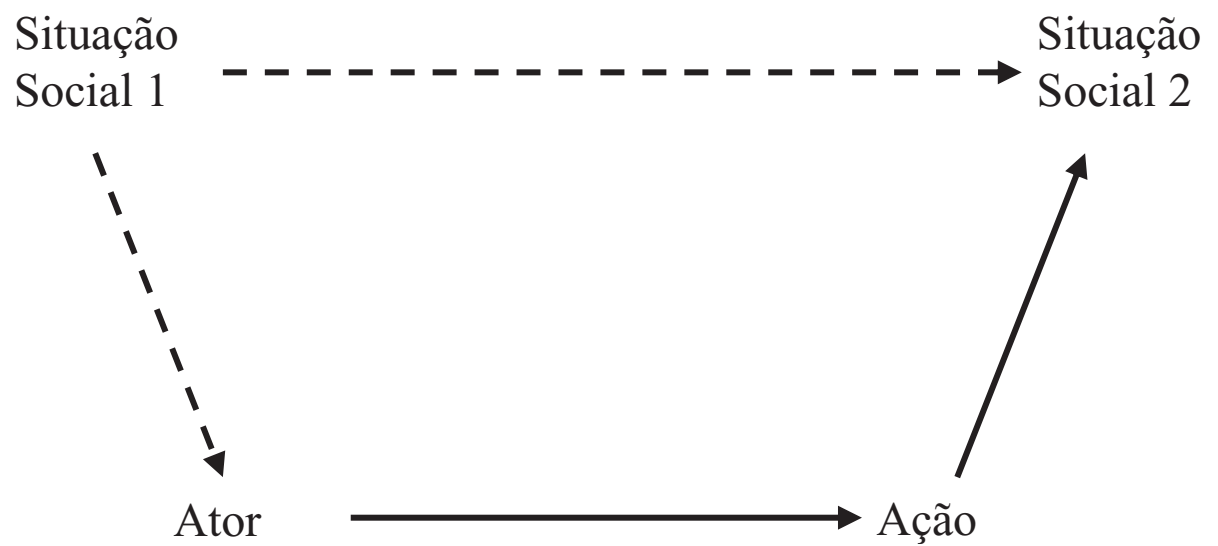

Gráfico 2.1 - O modelo micro-macro no individualismo metodológico moderado

Esse individualismo metodológico moderado tem implicaçóes importantes. Em primeiro lugar, ele permite uma orientaçáo sociológica fortemente matematizada. Uma vez que tenhamos captado os atributos nomológicos dos componentes do nível micro - no caso da sociologia, a açáo social - não precisamos mais de informações empíricas suplementares para estipular quais seriam os arranjos organizacionais possíveis e para deduzir os fenômenos macro do conhecimento que adquirimos sobre as regularidades das açóes. O recurso à realidade social é necessário apenas para fins de comprovaçáo empírica. De meu ponto de vista, isso não passa de uma ciência de sofá.

Em Hartmut Esser encontramos um modelo de relação micro-macro que faz uso de explicaçóes fortes e que elabora complexos modelos formais para analisar as chamadas regras de transformaçáo. Para tanto, ele diferencia entre modelos situacionais - em especial a teoria dos jogos - e os modelos processuais - entre os quais podemos apontar o modelo dos ciclos de valores. Esses modelos formais são "algoritmos mais ou menos complexos através dos quais a agregaçáo de atos individuais converte-se em fenômenos tipicamente coletivos [...]. A depender da distribuição das características individuais dos atores emerge certo processo de interação entre eles que, por sua vez, têm como desenlace efeitos coletivos" (ESSER, 1999, p. 23). E mais: "é exatamente no caráter formal dos modelos que se mostra a fecundidade desse procedimento, pois é somente através dele que podemos identificar e esclarecer fenômenos emergentes que, em princípio, parecem improváveis". Propriedades emergentes fracas, situadas no nível macro, podem ser deduzidas matematicamente, desde que tenhamos conhecimento das leis que determinam as açóes. É nesse 
procedimento dedutivo que reside o caráter forte do modelo de explicação adotado.

\section{Individualismo metodológico radical}

Não temos espaço aqui para descrever as diferentes variantes do individualismo metodológico. ${ }^{12}$ Prefiro partir da perspectiva adotada por Esser para tratar do chamado problema da transformação. Esser tenta pensar o problema da transformação (como efeitos individuais transformam-se em fenômenos coletivos) através de um modelo que diferencia entre as "condiçóes" da transformação e as "regras" de transformação. Para entender as condiçôes e as regras de transformação devemos adotar apenas procedimentos analíticos e formais que demonstrem quais os efeitos empíricos do nível individual sobre os macrofenômenos coletivos (ESSER, 2000, p. 24) ${ }^{13}$. As descriçóes dos efeitos individuais no processo de transformação não devem ser acompanhadas por proposiçóes sintéticas. Para que o argumento da transformação seja considerado válido, basta apenas que essas regras analíticas sejam consideradas verdadeiras em termos de suas relaçóes lógicas. Hartmut Esser define os fenômenos coletivos através das regras de transformação e são elas que explicam como, a partir do efeito combinado das açóes sociais, tais fenômenos são gerados (ESSER, 2000, p. 16). Fica claro, nesse caso, que as propriedades emergentes não podem ser interpretadas como elementos presentes apenas no nível coletivo, mas não nos seus componentes individuais ${ }^{14}$. A solução do problema macro-micro através de proposiçóes analíticas envolve necessariamente a redução ontológica e epistemológica do nível macro aos seus componentes micro,

12 Para a revisão do problema holismo e individualismo em perspectiva individualista, veja-se Vanberg (1975) e Bohnen (2000).

13 As regras de transformação institucional não possuem caráter analítico (ESSER, 2002, p. 22). No entanto, em outros momentos ele defende uma posição distinta quanto às regras e condições. As condições de transformação são chamadas de condições de partida (ESSER, 2000, p. 17), ainda que elas se pareçam, praticamente, com as leis ou, pelo menos, regularidades quase nomológicas. Enfim, suas asserções quanto a esse problema me parecem ser contraditórias.

14 Nesse caso, pode-se falar de resultantes ou de características herdadas: "características resultantes resultam diretamente das mesmas caracteristicas das partes e, portanto, delas podem ser deduzidas" (HOYNINGEN-HUENE, 1994, p. 183). As regras de transformação de agregados coletivos (bem como as definições parciais) enunciadas por Esser me parecem ter como objetivo servir como uma descrição de resultantes desse tipo. Quem está convencido da existência de fenômenos emergentes fortes rejeita esse procedimento de definições parciais como desnecessário e equívoco. Elas não são mais do que definições arbitrárias de características existentes no nivel da totalidade mesma. 
quer dizer, uma eliminação do nível macro, ou ainda, uma equiparação de identidade entre ambos. Trata-se, portanto, de um reducionismo ainda mais radical do que aquele do individualismo metodológico moderado. Como realidade ontológica, o nível sistêmico possui propriedades emergentes fracas que, por sua vez, precisam ser compreendidas por explicaçóes fortes, ainda que essas explicaçôes sejam apenas lógicas, ou seja, não se tratam de conexôes entre fenômenos reais (por isso o juízo é analítico e não sintético, ou seja, causal). O individualismo metodológico radical não admite a existência de efeitos emergentes, pois para ele a problemática da transformação tem um caráter essencialmente analítico. Por essa razão, essa posiçáo náo pode adotar a relaçáo causal ascendente (ou mesmo relação causal descendente) já que, em última instância, o nível macro sequer existe ${ }^{15}$. A única coisa que existe, de fato, são as relaçôes causais resultantes das interaçóes entre os próprios atores sociais ${ }^{16}$, em outras palavras, uma "same-level causation" restrita ao plano micro ${ }^{17}$.

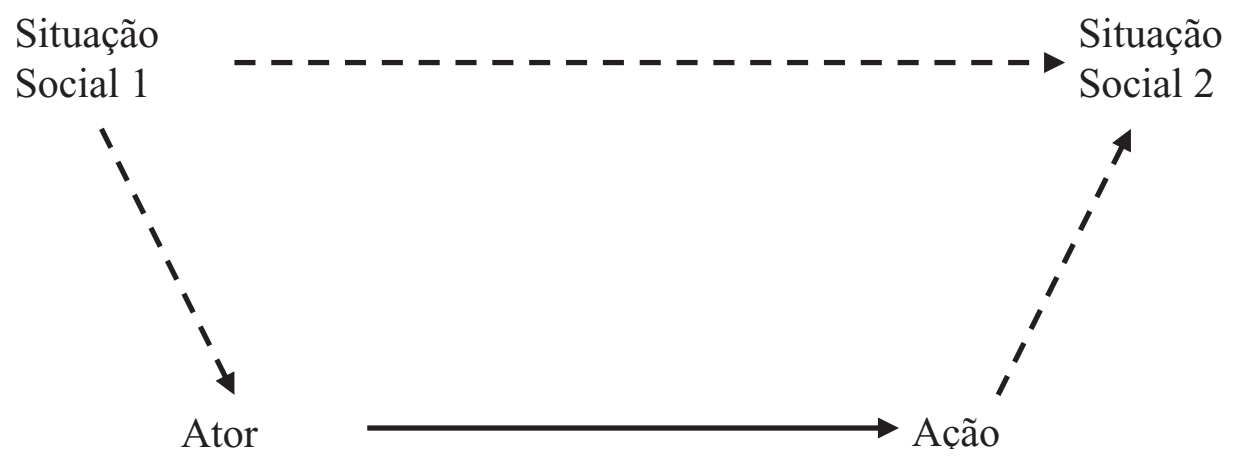

Gráfico 2.2 - O modelo micro-macro no individualismo metodológico radical

15 Concordo com Michael Schmid quando ele sustenta que o argumento ontológico é incompativel com o individualismo metodológico radical. Consequentemente, ele defende uma posição antirreducionista com componentes emergentes. No entanto, não se trata de uma posição idêntica na medida em que, ao estilo da escolha racional, compreende as influências macrossociais como estímulos (SCHMID, 1996, p. 75 e 80).

16 Veja-se também a apropriação que Adam Przeworski faz dessa dissolução dos efeitos contextuais no nivel individual.

17 Essa teoria da ação não precisa, obviamente, ser apenas de tipo mentalista, mas pode também adotar fundamentos neurofisiológicos, como ocorre no caso das teorias comportamentalistas. Dessa forma, um programa de pesquisa radi-calmente reducionista alcança pretensões unificadoras. 


\section{Holismo metodológico radical}

O holismo metodológico radical também postula uma same-level causation, mas ela é restrita ao nível macro. Seu princípio fundamental é o pressuposto da emergência forte, tal como encontrada na clássica definição de Durkheim. Em suas Regras do Método Sociológico e, principalmente, em seu artigo Representaçóes individuais e representaçóes coletivas, podemos encontrar posiçóes que hoje designamos como emergentistas, como bem mostrou Keith Sawyer (2002). Outros representantes contemporâneos desse tipo de holismo são, por exemplo, Peter Blau, o neoinstitucionalismo e a sociologia das organizaçóes. Inspirado na tese da divisão do trabalho de Durkheim e polemizando com George C. Homans, Blau formulou uma lei macrossociológica que, segundo a crítica, não só possui um caráter funcionalista, mas também capacidade explicativa reduzida (HOMANS, 1970, p. 325 e ss.): O aumento no tamanho de uma organização formal dá origem à diferenciaçóes estruturais ao longo de várias direçôes" (BLAU, 1970, p. 333). Na sociologia neoinstitucionalista encontramos a seguinte hipótese causal: quanto maior a dependência de uma organizaçáo em relaçáo à outra, mais ela tende a se igualá-la em sua estrutura, clima e comportamento" (DIMAGGIO; POWELL, 2000, p. 162). Entretanto, a formulação de tais leis macrossociológicas não significa que não se possa afirmar algo a respeito dos atores e suas interaçóes que, neste caso, são explicadas a partir dos efeitos causais que emergem das entidades macro, como o fazem Peter Blau e o novo institucionalismo sociológico. ${ }^{18}$ Do ponto de vista da perspectiva emergentista, fundamentos microssociológicos não só são necessários, como também desejáveis. Até que ponto elas devem recorrer a uma teoria da ação permanece a critério de cada teórico o que, segundo meu entendimento, não se justifica:

Macroestrutura $1 \quad$ Macroestrutura 2

Gráfico 2.3 - o modelo macro-macro no holismo metodológico radical

18 A análise dos microfundamentos desse novo institucionalismo sociológico é feita por Lynne Zuzker (199I). No caso de Blau, veja-se Blau (1978). 
Em favor desse programa de pesquisa macrossociológica existe um argumento oriundo do debate sobre as novas concepçóes de emergência. Essas teorisa surgiram no âmbito da filosofia e da psicologia e discutem a problemática da relaçáo entre alma e corpo (ou mente e cérebro), mas acabaram sendo importadas para a sociologia: trata-se do argumento das "realizabilidades múltiplas" e das "disjunçóes selvagens" (SAWYER 2001, p. 556; HEINTZ, 2004, p. 9). De forma sucinta, o primeiro desses argumentos afirma que leis macrossociológicas podem efetivar-se de modo diferenciado no nível micro. O segundo argumento significa que, em função dessa efetivação diferenciada, as hipóteses formuladas para explicar o que ocorre no nível micro não podem ser encaradas como leis:

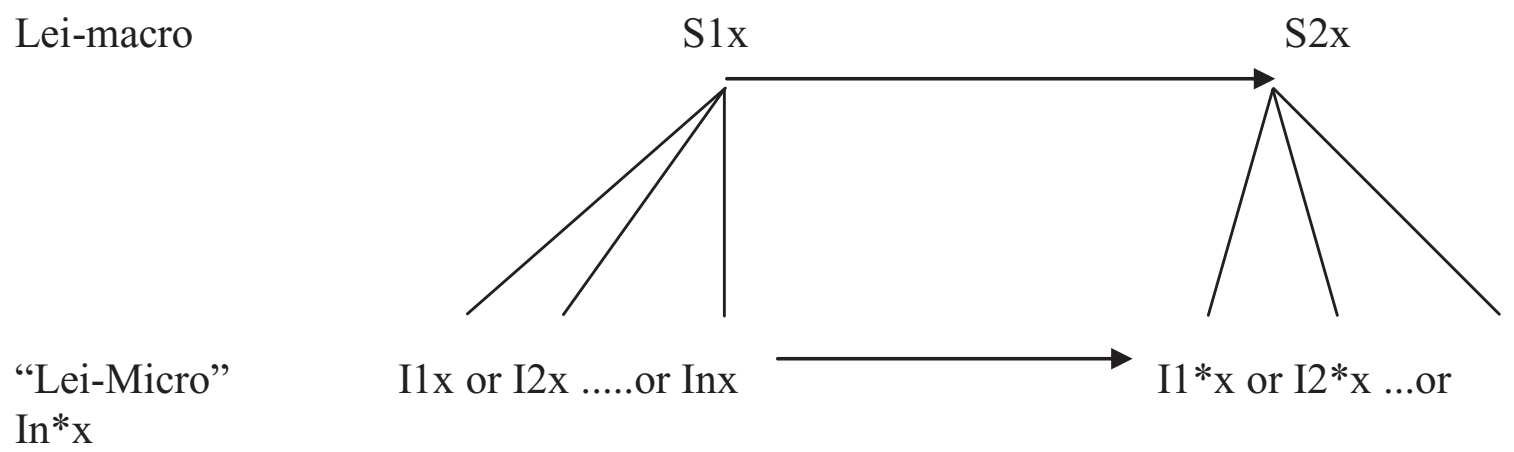

Gráfico 2.4 - Realizabilidade múltipla e disjunção selvagem

A ideia correspondente é a de que, tendo em vista tais disjunçóes (sejam elas lógicas ou relacionais), afirmaçóes sobre o nível micro não podem ser aceitas como proposiçóes nomológicas. ${ }^{19}$ Em meu entendimento, esse argumento toca em um ponto central do debate sociológico sobre o individualismo e holismo metodológico. $\mathrm{O}$ principal representante de uma concepçáo nomológica de individualismo metodológico é, atualmente, a teoria da escolha racional. Essa perspectiva postula uma teoria da ação de caráter geral e universal. Ela sustenta que todas as "leis", ou melhor, que as regularidades do nível micro, podem ser reduzidas à seguinte fórmula: $I x=>I^{*} x$, ou seja, a uma lei válida universalmente e sem disjunçóes. Ainda que, no nível micro, as condiçôes iniciais possam ser bastante variáveis, o fato é que existe apenas

19 Ninguém sabe exatamente o que qualifica certas proposições como nomológicas Esses, como, aliás, muitos outros temas da filosofia da ciência, são apenas argumentos de plausibilidade. 
um tipo de proposição nomológica ${ }^{20}$. Ora, o argumento da realizabilidade múltipla sustenta exatamente aquilo que a teoria da escolha racional nega. Uma perspectiva weberiana que trabalha com múltiplos tipos de ação pode enfrentar tranquilamente esse problema, ${ }^{21}$ algo que a posição de Esser (que é um teórico da escolha racional), que diz inspirar-se em Weber, não consegue, pois ele insiste na formulação de uma teoria da ação válida universalmente (ESSER, 2003).

$\mathrm{Na}$ minha perspectiva a sustentação desse argumento pode ser avaliada dessa forma: apenas aqueles que, como Weber (aqui tomado como modelo), estão dispostos a admitir princípios ou tipos de ação diversificados (leis ceteris paribus) podem superar o desafio posto pela teoria da realizabilidade múltipla e da disjunçáo selvagem. No entanto, essa possibilidade só será verdadeira se for possível demonstrar, de forma concreta, que leis macrossociais só existem realmente quando efetivadas através de mecanismos variados situados no nível micro. Isso seria um indicador para a existência de uma same-level causação no nível macro.

\section{Holismo metodológico moderado}

O holismo metodológico moderado parte do princípio de que náo existem leis causais no nível macro, ou seja, ele aceita o argumento da realizabilidade múltipla. Essa posição é diferente de todas as demais, pois ela entende que podemos aceitar tanto a existência de fenômenos emergentes fortes quanto fracos. Nessa medida, ele compartilha com o holismo ontológico a premissa da causaçáo descendente das propriedades emergentes fortes e com o individualismo metodológico moderado a tese da causaçáo ascendente dos fenômenos emergentes fracos. Em relação ao seu modelo explicativo, essa posição também se orienta, como o individualismo metodológico moderado, pela sequência macro-micro-macro - a causalidade social só ocorre através da ação humana - mas, e aí está a diferença, admitem-se os efeitos causais do nível macro sobre o nível micro, como é o caso da influência das instituiçóes sobre os atores. Na medida em que, no âmbito das correlaçóes causais,

20 A teoria da escolha racional só reconhece um tipo de proposição dessa natureza, dito de modo geral, o ator que ma-ximiza seus interesses.

2I Um holismo metodológico moderado de feição weberiana, como aqui defendemos, tem que se confrontar com esse argumento. 
fenômenos de tipo macro desempenham efeitos institucionais, eles só podem operar através de explicaçóes causais fracas. Caso contrário, explicações fortes também são possíveis.

Em lugar de um único eixo nomológico, como no individualismo metodológico, o holismo metodológico moderado possui três eixos teóricos (Gráfico 2.5). ${ }^{22}$ Ao lado da lógica da situaçáo ele considera ainda os efeitos diretos das instituiçóes ou das motivaçóes sobre os atores. Em lugar de uma teoria universal da ação ele sustenta, baseando-se em Weber, princípios múltiplos de ação, ou seja, uma maior quantidade de leis de ação do tipo ceteris paribus. Por fim, quanto à relaçáo entre micro e macro, ele enfraquece as premissas do individualismo metodológico moderado: nem todas as explicaçóes são consideradas fortes: as instituiçóes sociais, por exemplo, são concebidas como entidades fracas. Portanto, o que o holismo metodológico moderado aceita no que concerne a relação de causalidade do nível macro sobre micro, ele recusa novamente quando se trata de avaliar o peso dessa mesma relaçáo.

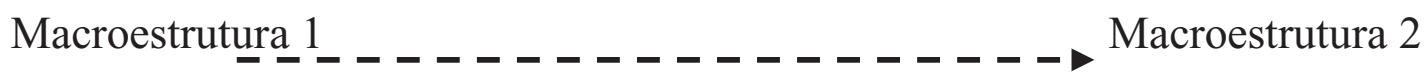

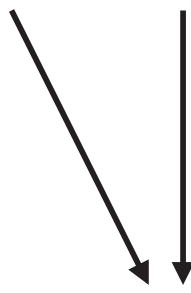

Ator

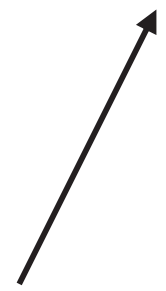

Acão

Gráfico 2.5 - O modelo micro-macro no holismo metodológico moderado

O primeiro eixo teórico do holismo metodológico moderado considera os efeitos do nível macro sobre os atores. Ao lado dos estímulos motivacionais ${ }^{23}$ que, segundo o modelo da teoria da escolha racional, são denominados de lógica da situação, mas que no holismo metodológico moderado são compreendidos

22 O que significa que já não se trata mais de um modelo explicativo (macro-micro-macro), mas de uma sequência explicativa triádica.

23 Custos e utilidades, por exemplo, são considerados pela TER como estímulos positivos ou negativos (veja-se OPP, 2004, p. 45). 
como efeitos reais, desdobram-se efeitos diretos das instituiçóes sobre os atores. No livro As instituiçóes impregnam os indivíduos, organizado por Martin Held e Hans Nutzinger (1999, p. 8) encontramos esta rica constatação: "as instituiçóes moldam os indivíduos, suas preferências, representaçóes valorativas, normas internalizadas, suas motivaçóes intrínsecas e suas visóes sobre direitos e obrigaçóes, status, concepçóes de justiça, equidade e muito mais”.

Essa frase mostra que esses economistas heterodoxos se deslocaram do individualismo metodológico para o holismo metodológico moderado. É claro que, além das instituiçóes, precisamos considerar também os efeitos de outras entidades macroestruturais. No entanto, quem são, concretamente, tais entidades, ainda é uma questão a ser pesquisada, tanto teórica quanto empiricamente. No livro acima citado, além das instituiçóes, encontramos artigos que discutem algumas dessas entidades, como os grupos sociais. No artigo de Ekkehrt Schlicht (p.166), em particular, temos uma rica discussão dos efeitos comportamentais gerados por processos de institucionalizaçáo alternativa e sobre seus efeitos em termos de diferenciação de preferências. Tais efeitos não podem ser explicados de forma mecânica a partir do esquema estímulo-resposta. Dentre os exemplos apontados por ele temos os efeitos derivados da institucionalizaçáo da propriedade privada, dado que eles sáo diferentes entre proprietários e usuários. Levar em consideração a diferença na estrutura da propriedade no permitiria, por exemplo, entender as diferenças entre empresários que atuam no ramo da Franchise ou em cadeias de lojas.

Ao consideramos os efeitos do nível macro, em especial das instituiçóes, sobre os atores, somos naturalmente conduzidos ao segundo eixo teórico de nossa proposta: a teoria da ação. Nesse campo podemos reconhecer a seguinte correlação: na medida em que admitimos a existência de macrodeterminaçáo temos que trocar uma visáo monoliticamente racionalista de ator social por categorias motivacionais pluralistas, ou seja, temos que transitar de uma teoria universalista para uma teoria pluralista que reconhece a multiplicidade de princípios que move a ação social. Portanto, no nível individual, podemos admitir apenas a existência de leis ceteris paribus, em suma, tipos ideias de ação e, a partir deles, tipos de ação real. Conforme afirma Ulrich Krause (1999, p. 66):

Uma vez que uma visão unificada do ator como racional e egoísta é superada em nome de uma visão que reconhece nele outras propriedades, teremos maior dificuldade de ancorar a explicação das instituições sociais em atores racionais; por outro lado, será mais fácil ex- 
plicar os efeitos dessas mesmas instituições sobre os indivíduos. Esse efeito retroativo das instituições sobre os indivíduos não pode ser captado nessa verdadeira caixa-preta que é a teoria da escolha racional, mas ele fica muito mais claro tão logo ela for aberta e identificarmos também os caracteres normativos e morais dessas instituições.

Caso queiramos, realmente, captar os efeitos causais das instituiçóes, temos que levar em conta as demais características dos indivíduos, como seu caráter moral por exemplo; o que significa que temos que nos despedir da fixação unidirecional no critério da racionalidade de fins e meios. A partir dessa virada epistemológica deixamos definitivamente para trás a concepção atomista do individualismo metodológico moderado. O pressuposto central da teoria da escolha racional é justamente o de que os elementos individuais jamais se modificam em suas características categoriais [intrínsecas] e que toda mudança qualitativa no nível macro é apenas uma mudança na composição desses elementos individuais. Defino características categorias como objetos de cadeias causais. No caso da teoria da escolha racional, por exemplo, o ator tem apenas uma característica categorial [intrínseca]: o desejo de maximizar suas preferências ${ }^{24}$. Consequentemente, nessa teoria, as características do nível macro são apenas o resultado do modo como estáo combinados os próprios atores sociais, quer dizer, do modo como eles se relacionam entre si. No holismo metodológico moderado, ao contrário, admitem-se os efeitos macrodeterminantes de estruturas emergentes fortes, pois estruturas situadas no nível macro também exercem efeitos sobre as entidades do nível micro, o que significa, ao final, que as características categoriais dos microcomponentes podem mudar. Concretamente, mudanças institucionais podem ocasionar mudanças motivacionais e, dessa forma, modificar as disposiçóes individuais para agir.

Resta tratar, agora, do terceiro eixo do individualismo metodológico moderado, ou seja, da relação micro-macro. Para o caso de fenômenos emergentes fracos, vale o mesmo que no individualismo metodológico moderado: explicaçôes fortes com o auxílio de modelos formais. A depender da composição dos atores sociais, podemos deduzir diferentes fenômenos coletivos. Já para os fenômenos emergentes fortes vale, ao contrário, o modelo das regras institucionais de Esser (2001, p. 21), o que, no nosso caso, significa que se

24 Mesmo a tentativa de Hartmut Esser em integrar os tipos weberianos de ação em uma teoria de tipo de universal reconhece apenas uma característica categorial dos atores. 
trata de explicaçóes fracas para fenômenos emergentes fortes. A lei contém, no explanans, um antecedente (componente "se") que conecta açóes individuais (ou efeitos) e regras institucionais e ainda um consequente (componente "então") que são os fenômenos coletivos. O exemplo de Esser é a transformação dos votos individuais (efeitos individuais - ou antecedentes) em cadeiras no parlamento (fenômeno coletivo-consequente) através de regras institucionais (regras de composiçáo na parte antecedente da lei), caso dos sistemas eleitorais majoritários ou proporcionais ${ }^{25}$.

Caso queira satisfazer suas próprias exigências metodológicas, o individualismo metodológico moderado necessita deduzir essas regras institucionais de uma determinada composição dos atores sociais, sem poder derivá-las de estruturas coletivas. Caso contrário, ele estaria explicando estruturas coletivas através de outras estruturas coletivas, sem ancorá-las no nível micro. Nesse caso caberia falar do regresso infinito ao holismo ${ }^{26}$. Para o holismo metodológico moderado esse problema náo existe, pois ele aceita a existência de efeitos institucionais, ainda que eles sejam fenômenos históricos que requeiram explicaçóes fracas, e não leis da ação válidas de modo trans-histórico. Isso significa dizer que no holismo metodológico moderado, antes do surgimento de um macrofenômeno com propriedades emergentes fortes, não é possível explicá-lo previamente. É apenas paulatinamente que podemos identificar as condiçóes gerais que determinaram a emergência desse fenômeno (BÜNTRUP, 2001, p. 68). É somente a partir da ocorrência anterior que prognoses são possíveis.

$\mathrm{O}$ individualismo metodológico possui exigências muito extremas, no limite, inatingíveis. Quando da primeira ocorrência de um fenômeno emergente fraco - os únicos que ele admite - ele acredita poder prever suas principais características, afinal, ele pode identificar qualquer variação na composição dos elementos, tendo em vista que, supostamente, conhece todas as características dos atores. Essa é a razão pela qual modelos computacionais são tão valorizados nesse modelo. Para o holismo metodológico moderado tais modelos são úteis apenas em relação a fenômenos emergentes fracos, pois para os

25 Esse exemplo tem o defeito de sugerir que tais regras são mecanismos explicativos fortes, mas não devemos confundir exigências legais com processos sociológicos.

26 Argumentação similar encontra-se em Kappelhoff (1997). 
fenômenos emergentes fortes precisamos recorrer à pesquisa histórica. $\mathrm{O}$ individualismo metodológico moderado tende para uma sociologia fortemente matematizada, já que ele admite apenas a existência de fenômenos fracos que podem ser explicados atemporalmente através de esquemas lógico-matemáticos. Quanto ao individualismo metodológico moderado, no medida em que ele admite a existência de fenômenos emergentes fortes, favorece-se a pesquisa empírica, ou seja, ele está muito mais próximo de uma sociologia histórica.

\section{Modelos de explicação sociológica em Max Weber}

A obra A ética protestante e o "espírito" do capitalismo [doravante EP] é considerada, ainda hoje, um modelo de análise sociológica. Foi David C. MacClelland (1961) que demonstrou, pela primeira vez, que por trás desse estudo encontra-se o modelo macro-micro-macro. De fato, nessa pesquisa encontramos o modelo explicativo de Weber colocado em uso: ele vai do nível macro até o micro e, após, percorre o caminho inverso. Wolfgang Schluchter mostra ainda que podemos localizar nesse modelo um nível intermediário [nível meso] ${ }^{27}$, relacionado tanto com o nível micro quanto com o macro. O espírito do capitalismo, entendido como uma forma específica de orientação econômica da ação, - objeto da análise - é o resultado da influência da ética religiosa do protestantismo ascético sobre a conduta de vida. $\mathrm{O}$ aconselhamento pastoral provoca uma mudança na disposiçáo econômica até então vigente. Por meio de uma ascese vocacional intramundana ela é paulatinamente substituída, na esfera econômica, por uma orientação da ação fundada em valores. O espírito do capitalismo é a forma vocacional secularizada mais adaptada ao moderno homem econômico e ele determina o tipo de conduta de vida vigente na vida econômica.

Mas, ainda que Weber siga o modelo macro-micro-macro de análise, a mim parece muito claro que ele em nada se assemelha àquele que é geralmente postulado pela teoria da escolha racional, que entende a influência do nível macro sobre micro apenas como estímulo. Para Weber, a influência das estruturas coletivas sobre a conduta de vida dos atores tem um caráter

27 A introdução de novos niveis de análise não altera em nada as características de nosso modelo. Da mesma forma, não há nenhuma necessidade que as explicações do nível macro pelo nível micro recorram sempre aos atores individuais, pois também podemos recorrer aos atores coletivos, como mostram Schluchter (2003, p. 60) e Coleman (199I, p. 3-6). 
motivacional. A produção da influência motivacional do profissional moderno determina, em primeiro lugar, o fato de que ele se comporte dessa forma em relaçáo aos estímulos advindos do mercado (ou de outras instituiçóes). A ética protestante de Max Weber mostra não só que ele segue o modelo explicativo macro-micro-macro, mas também que ele reconhece os efeitos do nível macro sobre o nível micro. Por esse motivo, faz todo sentido classificá-lo no campo do holismo metodológico moderado. Do ponto de vista da teoria da ação também é indiscutível que, na EP, ele não defendeu nenhuma teoria universal da ação, na medida em que reconhece diferentes tipos de orientação do agir que surgem ou desaparecem em função dos efeitos macrossociais.

Para ter uma ideia mais clara e completa do modelo explicativo de Weber, precisamos aprofundar um pouco mais o modo como ele concebe a relaçáo micro-macro. Para ajudar-nos nessa tarefa, mais do que nos fixamos apenas na EP, podemos usar como exemplo também a sua sociologia ou tipologia da dominação (WEBER, 1980, doravante WuG).

Ao contrário da sugestáo de Esser, que entende que tipologias náo possuem qualquer poder explicativo, já que elas são apenas etapas preparatórias para a elaboração de teorias, desejo demonstrar que os tipos ideais de dominação legítima de Max Weber devem ser entendidos, em princípio, como modelos explicativos ceteris-paribus, ou seja, como leis de instanciaçáo, ou ainda, como leis micro-macro (ESSER, 1993, p.56). É claro que Esser está correto quando afirma que tipologias não são explicaçóes. No entanto, tipos podem assumir o lugar de leis em explicaçóes causais nomológico-dedutivas e, dessa forma, são muito mais do que meras etapas preparatórias (seja como terminologias ou classificaçóes para a elaboração de teorias ${ }^{28}$. A tese fundamental da tipologia weberiana da dominação - ainda que isto não esgote seu conteúdo - é a seguinte: quando uma determinada forma de legitimidade (carismática, tradicional, legal) é compartilhada pelos atores sociais como uma representação válida e obrigatória então ela possui uma estrutura organizacional [quadro administrativo] correspondente a essa legitimidade. Dessa maneira, podemos interpretar cada um dos três tipos de dominação como coexistência de leis

28 Não temos como esclarecer todos os problemas conexos com o tema dos tipos ideais. No entanto, cabe acrescentar que ele constitui um instrumento para a atribuição de fatores causais de fontes distintas. 
ceteris paribus ${ }^{29}$. No entanto, mesmo que os tipos de dominação possam ser vistos como leis instanciação, necessitamos também dizer alguma coisa sobre os atores sociais, ou seja, os tipos de dominaçáo não devem ser interpretados, obviamente, como se eles fossem leis "para a ação". Em outros termos, o que estou tentando sustentar é apenas que a correspondência entre os princípios de legitimação e os aparatos administrativos que são próprios de cada um dos tipos de dominação pode ser interpretada como leis de instanciação. Seguindo-se esses pressupostos, uma sentença nomológica da teoria da dominação legal poderia ser esboçada dessa forma: para uma ordem de dominação vale ceteris paribus que, quando os atores compartilham a crença na legalidade da ordem estatuída e reconhecem um governo por ela regulado, então podemos encontra nessa ordem os seguintes elementos estruturais: exercício contínuo da administração vinculada a determinadas regras, delimitação de competências, princípio da hierarquia etc.

Os elementos estruturais da dominação legal são propriedades emergentes fortes situadas no nível "sistêmico" e são elas que precisam ser explicadas ${ }^{30}$. Ora, elas são explicadas através de determinadas propriedades dos atores, a saber, pela crença compartilhada na legalidade dessa ordem. De meu ponto de vista, na explanação sociológica instanciada de fenômenos emergentes fortes, certos conteúdos culturais - que é justamente o caso do tipo de legitimidade que define cada tipo de dominação - podem representar aqueles componentes que nos dizem algo sobre a configuração estrutural dos componentes do nível micro, ou seja, dos atores. Percebemos, entáo, que a explicação sociológica instanciada de fenômenos emergentes fortes contém uma macrossociologia completa que, contudo, precisa ser complementada no explanans com um componente teórico no nível do agente (Gráfico 6). A obliteração desse componente individual tem como consequência o encurtamento das instâncias explicativas na coexistência de leis de tipo macrossociológico. No caso da sociologia weberiana da dominação teríamos como conclusão a seguinte lei: a estrutura de uma ordem política corresponde ao tipo de legitimidade dessa ordem.

29 Agradeço a Alfred Bohnen ter me chamado a atenção para a coexistência dessas leis. O tipo carismático de domina-ção contém elementos dinâmicos que resultam de sua institucionalização e objetivação. Trata-se do chamado "problema da transformação do carisma" (SCHLUCHTER, 199I).

30 Wolfgang Schluchter (1996, p.I20) destaca que Weber reconhece fenômenos emergentes fortes, embora não deixe claro se se tratam de fenômenos emergentes fortes ou fracos. 


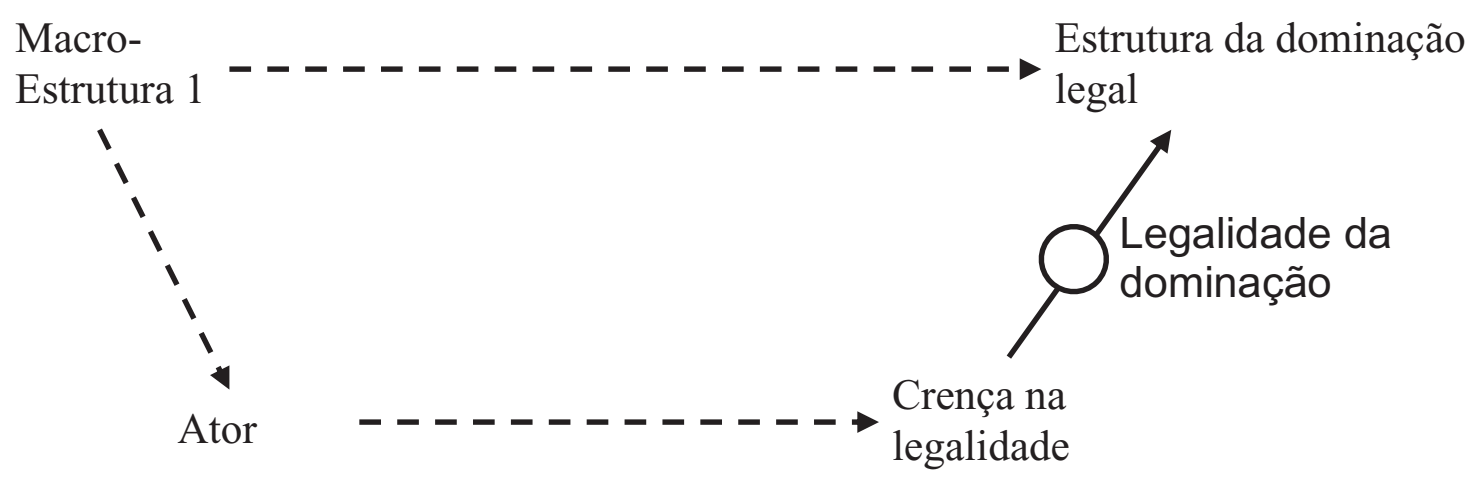

Gráfico 6 - A sociologia da dominação de Weber lida como leis de instanciação da relação micro-macro

Além disso, é perfeitamente possível que a relação macro-micro, ou seja, os efeitos causados pelo nível macro sobre os componentes do nível micro possa ser repetir, mas, dessa vez, como um componente que, na explanação das instâncias explicativas (relação micro-macro), descreve a configuração estrutural dos elementos do nível micro, ou seja, a sua composiçáo. Isso seria o caso, por exemplo, quando na reproduçáo de uma determinada ordem política houvesse a conservação das mesmas formas de estrutura e legitimidade. A legitimidade da ordem política teria que ser procurada primariamente no conteúdo macro com o qual se inicia o modelo macro-micro-macro e, secundariamente, na relação micro-macro como configuração estrutural do Explanans na explicação instanciada (Gráfico 7).

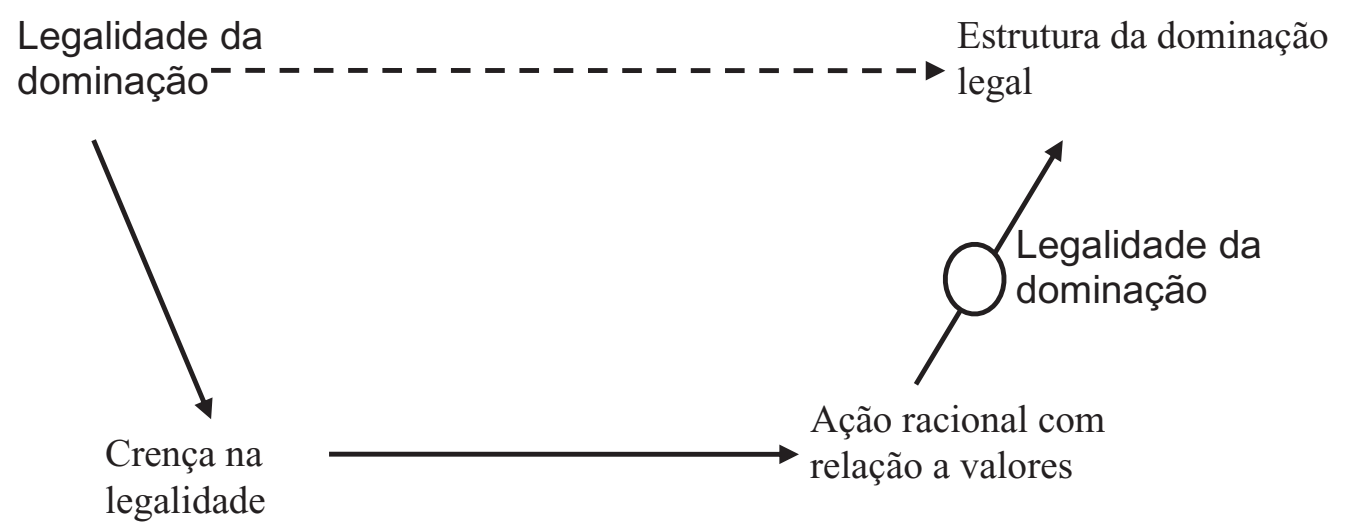

Gráfico 7 - A sociologia da dominação segundo o modelo macro-micro-macro 
Nós não poderíamos fundamentar essas "leis" weberianas de instanciação de forma adequada se simplesmente as derivássemos das características dos atores sociais, como é necessário no caso da explicação de caracteres emergentes fracos. Trata-se, em cada um dos diferentes tipos de dominação, de propriedades emergentes fortes, ainda que explicáveis de modo fraco. Tais explicaçóes de tipo fraco não podem ser procuradas na teoria dos jogos ou outras similares, mas somente lidando-se com a realidade histórica. A sociologia weberiana da dominação, portanto, deve ser compreendida de modo histórico, e não de modo abstrato.

A análise do modelo sociológico utilizado por Weber no estudo da ética protestante e dos tipos de dominaçáo nos permite chegar a uma importante conclusão. Weber segue o modelo explicativo macro-micro-macro não no sentido do individualismo metodológico, mas do holismo moderado, combinando a tríade macrodeterminação (macro-micro), pluralidade de orientaçóes de ação (micro-micro) e explicaçóes fracas por meio de leis de instanciação (micro-macro). Outro argumento para sustentar porque essa perspectiva metodológica, que interpreta Weber como um holsita moderado, é mais adequada do que uma interpretação individualista de tipo clássico, também pode ser encontrado na teoria weberiana da ação, em particular no seu caráter compreensivo-explicativo. É o que vamos explicar agora.

\section{Compreensão explicativa}

O problema micro-macro ou a problemática da emergência é uma questáo que ressurge continuamente nas discussóes ontológicas. $\mathrm{O}$ atual debate sobre a emergência ou causação descendente (macrodeterminação) se dá principalmente no contexto da problemática alma-corpo, ou seja, em um campo que é de extrema relevância para a sociologia. De fato, náo devemos crer que uma escolha por uma das posiçóes no debate alma-corpo não traga qualquer repercussão na sociologia. É como se cada sociologia pudesse ser alocada em um lugar desse debate. Isso é particularmente válido para toda sociologia de orientação individualista ou comportamentalista, ou seja, para toda sociologia que pretenda seguir o modelo macro-micro-macro. A questáo posta para cada um dessas perspectivas é a seguinte: em que medida a opçáo a favor ou contra e existência de propriedades emergentes fracas ou fortes no nível micro ou no nível macro pode ser coerente com uma ou com a outra. Isso significa 
que cada perspectiva sociológica decide-se a favor ou contra a emergência ou a macrodeterminação nos dois níveis: primeiro em relação ao nível social e psíquico (ou mais propriamente, no nível individual) e, secundariamente, em relação ao nível psíquico e físico (neurofisiológico).

Adotando o entendimento de que o paradigma weberiano deve ser lido como uma forma de holismo metodológico moderado, mostrei que a forma legal de dominaçáo pode ser considerada náo apenas como uma estrutura emergente de tipo forte, mas que ela também exerce alguma forma de macrodeterminação sobre o nível psíquico ${ }^{31}$. Mas, agora, além de olharmos para as estruturas, precisamos também discutir a teoria weberiana da ação, ou seja, o nível micro. Quais são as consequências derivadas da distinçáo weberiana entre comportamento e ação (ALBERT, 2002, p. 639; 2005, p. 160-165)?

Weber define ação como "um comportamento humano (tanto interno como externo, permitir ou omitir) quando e na medida em que o ator conecta a ela um sentido subjetivo" (WuG: 1). O comportamento reativo puro náo está ligado com nenhum sentido subjetivo. A ação com sentido pode ser explicada pelos motivos que lhes atribuem os atores, resultando daí uma conexão de sentido, seja esse sentido o resultado da escolha do próprio ator, seja ele o resultado da atribuição de sentido por parte do observador (WuG: 5). Razóes como motivos são, para Weber, a causa das ações. É somente em função desse dado que a compreensáo explicativa é possível: nós podemos compreender os motivos e ao mesmo tempo explicar suas causas. Quando os motivos são causas torna-se possível compreender explicativamente.

O que significa, para Weber, "explicar"? Explicar um evento particular significa - segundo Weber -, submetê-lo a uma regra (lei) (WuG:6). Do ponto de vista lógico, isso corresponde ao modelo nomológico-dedutivo. Na visão de Weber, a compreensão explicativa ou a explicação compreensiva fornece para a sociologia a possibilidade de ir além da mera observaçáo, tal como utilizada no âmbito das ciências naturais, pois esta se restringe a relacionar regras causais a processos e estruturas para, dessa forma, explicar eventos particulares (WuG:7). A contribuição da compreensão explicativa reside na possibilidade de compreender a ação dos indivíduos e é neste ponto que reside a

31 Relembrando que não se trata de nenhum determinismo, apenas de influências causais. 
especificidade da sociologia. A compreensão explicativa significa, pois, compreender as razóes dos atores e submetê-las a uma regra (lei). Isso nos possibilita unificar o modelo nomotético-dedutivo e o silogismo prático (que estáo ambos a serviço da compreensão). Podemos expressar isso da seguinte forma ${ }^{32}$ :

Lei: para cada pessoa $\mathrm{X}$ : quando $\mathrm{X}$ intenta produzir o estado desejado $\mathrm{E}$ e $\mathrm{X}$ crê que na situação dada ela pode ser produzida apenas mediante a ação $A$, então X procurará executar a ação $\mathrm{A}$.

Condições de partida: Intenção: Pessoa P deseja produzir o estado desejado E.

Crença: Pessoa P crê que na situação dada o estado desejado E pode ser produzida apenas através da ação A.

Ação: P procura executar A.

O silogismo prático necessita, portanto, recorrer a uma lei ou, na terminologia de Weber, a uma regra, a fim de que se possa deduzir do explanandum a explicação da ação ${ }^{33}$. Trata-se de um erro quando George Henrik von Wright, com seu argumento da conexão lógica, crê que não há necessidade de recorrer a qualquer lei para explicar o sentido da açáo e que basta deduzir logicamente tal sentido a partir das intençóes e opiniōes dos próprios atores ${ }^{34}$. As intenções ou planos formulados pelos atores são apenas as condiçóes de partida, mas para que elas possam ser realmente explicadas, precisamos relacioná-las com regras gerais. Os tipos weberianos de açáo são, em sua essência, regras ou leis desse tipo, pois eles postulam uma conexão lógica entre razóes e comportamentos (WuG: 5). Pela ótica da comprovação empírica, a tipologia da ação deve ser compreendia de forma probabilística (WuG: 5.f). No entanto, o princípio "razóes como causas" vale de modo estrito apenas para os dois tipos de ação racionais de Weber, ou seja, para os tipos racionais em relação a fins ou valores. É apenas em relação a estes dois tipos que a compreensão

32 Hartmut Esser (1999) e Schmidt (1996) defendem uma posição similar. Por essa razão, Rosenberg (1988) classifica Weber no campo do naturalismo.

33 Esse argumento nos permite responder as críticas de Michael Schmid (2004, p. 55I).

34 Contra esse erro de Whrigt (1977, p. 138) defendemos que essa conexão lógica é de tipo a-prioristico, ou seja, de caráter epistemológico. 
explicativa é inteiramente possível. Em relação aos outros dois tipos - tradicional e afetivo - é necessário efetuar algumas reduções. Além disso, é importante acrescentar que a explicação das açóes racionais necessita considera muito mais do que apenas a relação entre razão e comportamento: tais explicações precisam incluir também os correspondentes processos de ponderação e seleção de razóes. Nesse sentido, a teoria da escolha racional poderia ser integrada no conjunto do paradigma weberiano, mas, outras modalidades de açáo, especialmente aquelas que contenham componentes valorativos, também precisam ser desenvolvidas.

\section{Ação e redução}

Segundo Weber, a ação é um comportamento significativo resultante de razóes de caráter subjetivo. Ela se contrapóe a um comportamento reativo que não está motivado por razóes significativas (WuG: 1 ss.). Desta forma, fica implícito que conteúdos mentais (espirituais) podem influenciar processos corporais (físicos): minha vontade de ter um quarto aquecido e minha crença de que apenas pequenos pedaços de lenha podem ser queimados em meu fogáo influenciam causalmente meu comportamento corporal de cortar lenha. Conforme a teoria da emergência, estados mentais (de indivíduos físicos) são fenômenos emergentes e quando eles influenciam seus portadores físicos (causação descendente ou macrodeterminação) estamos lidando como propriedades emergentes fortes. Portanto, uma teoria da ação pensada no sentido de Max Weber, inclusive a teoria da escolha racional, parece implicar como pressuposto necessário uma concepção forte de emergência, incluindo a macrodeterminação (BRÜNTRÜP, 2001, p. 19 ss). Quem aceita este pressuposto, não tem mais como sustentar uma teoria de tipo reducionista.

$\mathrm{Na}$ verdade, quem assume posição em favor do individualismo metodológico moderado é obrigado a adotar uma posição contraditória, adotando a tese da emergência forte no que diz respeito a relação entre o físico e o psíquico e a tese da emergência fraca no que diz respeito a relaçáo entre o psíquico e o social. Tal posição requer uma justificação adequada. Para sustentar tal posição, o programa geral do reducionismo não pode ajudar como, aliás, reconhece, de forma velada, Hatmut Esser (2000, p. 12 ss.) ${ }^{35}$.

35 Uma tentativa similar de produzir uma teoria unificada da ciência através do princípio da redução pode ser encontrado em Feigl (1953). 
Caso classificássemos a teoria de Harmut Esser no campo do individualismo metodológico moderado, teríamos que levar sua teoria da ação até as últimas consequências. Isso significaria que a causalidade mental aí implicada (razóes como causas) exclui a possibilidade de uma reduçáo do psíquico a suas bases neurofisiológicas. O programa de um reducionismo abrangente, como o qual Esser claramente namora, acabaria inviabilizado. Somente o individualismo metodológico radical pode se comprometer integralmente com o reducionismo. Ele não admite nenhum fenômeno emergente, apenas a relação micro-macro explicada por meio de regras de transformação de caráter analítico. $\mathrm{O}$ caráter analítico dessas regras de transformação indica que aqui existe identidade entre fenômenos macro e micro e que um pode ser traduzido no outro. Isso também significa que sua teoria da ação não assume caráter ontológico. A equiparação entre estados mentais com fenômenos físicos acabaria por eliminar o caráter vivencialmente subjetivo de tais estados: nesse caso passamos a utilizar o vocabulário mentalista, mas sem ligá-lo ao seu significado próprio. $\mathrm{Na}$ prática, isso também significa a redução do caráter psicológico da ação a uma teoria fisicalista (neurofisiológica etc.). Uma versão aceitável desse modelo só seria possível caso a teoria sociológica da ação adotasse pressupostos fisicalistas ou neurofisiológicos. Uma sociologia com base na teoria da ação nada mais seria do que um episódio esquecido do progresso geral da ciência. Mas, este não é o caso no holismo metodológico moderado, no qual, ao contrário, a fundamentação da sociologia na teoria da ação constitui uma exigência incontornável.

Em relação as perspectivas individualistas, podemos escolher, fundamentalmente, entre três posiçóes ${ }^{36}$. Em primeiro lugar, um individualismo metodológico radical que utiliza o vocabulário mentalista de forma vazia, já que ele almeja sua ampla redução ao físico (e deve desejá-lo caso queria ser convincente). Em segundo lugar, o individualismo metodológico moderado, que interpreta a ação como um fenômeno emergente forte, mas que nega veementemente a existência de fenômenos sociais emergentes fortes no nível macrossocial. E, em terceiro lugar, o holismo metodológico moderado, que interpreta a ação e as instituições como fenômenos emergentes fortes, ou seja,

36 Poderíamos também incluir posições intermediárias, como a que sustenta a emergência forte em relação a ação e a tese da identidade no que diz respeito a relação micro-macro. Resta saber se elas são coerentes. 
capazes de macrodeterminação ${ }^{37}$. As duas posições mais coerentes são, à primeira vista, o individualismo metodológico radical e o holismo metodológico moderado ${ }^{38}$. Mas, entre essas duas, somente o holimo metodológico moderado é uma posição capaz de preservar tanto o caráter subjetivo-vivencial dos estados mentais ou psíquicos, quanto o aspecto voluntarista do agir.

\section{Conclusão}

O holismo metodológico moderado segue o modelo macro-micro-macro de explicação sociológica, ainda que o faça de modo diferente do individualismo metodológico. Ele não reconhece leis causais no nível macro, embora admita a existência de efeitos causais fortes que são derivados de fenômenos de tipo emergente, tais como normas, instituiçóes ou ordens legítimas, sobre os atores. Isso tem como implicação um antirreducionismo de princípio: a existência de efeitos causais do nível macro sobre o nível micro exclui a possibilidade de reduzir a própria relaçáo macro-micro à leis no âmbito micro, ou seja, a padróes nomológicos de ação. A real existência da macrodeterminação não pode ser reduzida a uma teoria que, obviamente, só conhece a microdeterminação. Por esse motivo, o holismo metodológico moderado é, em oposição ao individualismo radical e ao moderado, antirreducionista, e isso no que tange aos dois níveis de análise: o macrossocial (nível da estrutura) e o microssocial (nível da ação). No entanto, ele é antirreducionista apenas no que diz respeito aos fenômenos emergentes fortes, pois quanto aos fenômenos emergentes fracos e aos caracteres macrofenomênicos deles resultantes, continua valendo, evidentemente, a explicação redutiva.

O holismo metodológico moderado distingue-se do individualismo metodológico por assumir a existência de entidades sociais emergentes fortes que exercem macrodeterminação. Trata-se de um pressuposto ontológico. Já a característica distintiva em relação ao holismo metodológico radical é de ordem metodológica: o holismo metodológico moderado segue o modelo

37 O holismo metodológico moderado não deixa de admitir fenômenos emergentes fracos no nível macro. É o caso, por exemplo, das classes sociais. Podemos pensar também em certos comportamentos que, em relação à ação, possuem propriedades emergentes fracas.

38 Quem admite a existência de fenômenos emergentes fortes, caso do individualismo metodológico moderado, precisa admitir ainda uma série de postulados que não deixam de ser holistas, o que não deixa de ser uma contradição. 
macro-micro-macro de explicação e não se orienta pela busca de leis macrossociológicas. Existem diversos motivos para isso: aceito o pressuposto de que existem fenômenos emergentes simultaneamente fracos e fortes, bem como fenômenos macrossociais deles resultantes, não há como não seguir o modelo de explicação macro-micro-macro. Mesmo que fenômenos emergentes fortes pudessem ser modelados conceitualmente no nível macro, o fato é que fenômenos emergentes fracos e seus resultantes não nos permitem fazer isso. Nesse caso, a explicação necessita reportar-se, corretamente, ao nível micro.

Um argumento adicional em prol do modelo macro-micro-macro resulta do pressuposto de que, em diversos tipos de processos sociais, lidamos com o incremento ou recrudescimento de fenômenos emergentes. Expressando-nos teoricamente nos termos do institucionalismo (institucionalização ou des-institucionalização): no caso da formação de instituiçóes, pode ser que tenhamos que partir da descrição realista dos atores e de suas configuraçôes específicas para entender os processos emergentes daí resultantes. Isso significa que a entidade correspondente, que um teórico holista tenderia a explicar em termos puramente macro, surge apenas a partir da configuração de posiçóes individuais de um conjunto de atores. Um exemplo é a formação de um movimento carismático e a sua posterior institucionalização (LEPSIUS, 2003). A crítica ao caráter reificador da macrossociologia pode ser interpretada como incapacidade de compreender a dinâmica própria de processos sociais emergentes. Precisamos entender o fato de que o mundo social é, em diversos aspectos, muito mais fluido do que solidamente estruturado e, por essa razão, deve ser compreendido tendencialmente como processual.

Por fim, cabe-nos adicionar ainda mais dois argumentos em prol do modelo macro-micro-macro e contra qualquer tipo de sociologia puramente macroestrutural. O primeiro é a existência de fenômenos que se concretizam de forma múltipla, pois se, por um lado, eles são um indicador de causalidade no nível macro, por outro, eles excluem a possibilidade de um holismo metodológico radical. De todo modo, em nome do pluralismo teórico, não deixa de ser metodologicamente útil que tenhamos representantes de uma macrossociologia pura. Eles nos fornecem importantes estímulos heurísticos que, nos marcos do modelo macro-micro-macro, nos permite verificar empiricamente se, de fato, estamos diante de fenômenos de concretização múltipla. Caso sua existência seja constatada, cabe ao holismo metodológico complementar e não 
simplesmente suprimir tal perspectiva macrossociológica, pois em se tratando dos efeitos causais do nível macro, temos que partir da macrodeterminação, ou seja, da influência de fenômenos macroemergentes fortes no plano dos atores sociais. Procedendo-se assim, o modelo macro-micro-macro permanece intacto e pode ser visto como complementar ao modelo explicativo da macrossociologia. Além disso, ele representa um ganho em relação à sociologia macroestrutural, pois, como Weber já tinha afirmado, somente esse modelo permite a compreensão do sentido das açóes.

\section{Referências}

AGASSI, Joseph, 1975: Institutional individualism. The British Journal of Sociology, v. 26, p. 144-155, 1975.

ALBERT, Gert. Paretos hermeneutischer Positivismus. Eine Analyse seiner Handlungstheorie. Kölner Zeitschrift für Soziologie und Sozialpsychologie, v. 54, p. 625-644, 2002.

Hermeneutischer Positivismus und dialektischer Essentialismus Vilfredo Paretos.Wiesbaden: VS-Verlag für Sozialwissenschaften, 2005.

Agathe Bienfait, Steffen Sigmund und Claus Wendt: das Weber-Paradigma. Studien zur Weiterentwicklung von Max Webers Forschungsprogramm. Tübingen: Mohr, 2003.

BALOG, Andreas. Formen der ,Zerlegbarkeit' sozialer Phänomene. Ein Beitrag zum MikroMakro-Problem. Analyse und Kritik, v. 15, p. 168-191, 1993.

. Handlungen und Tatsachen. Weber und Durkheim über die „Objektivität“ des Sozialen. Berliner Journal für Soziologie, v. 14, p. 485-502, 2004.

BECKERMAN, Ansgar. Können mentale Phänomene neurobiologisch erklärt werden? In: G. Roth und W. Prinz (Hg.). Kopfarbeit. Heidelberg: Spektrum Verlag, 1996, p. 413-425.

BLAU, Peter M. In: Robert Borger und Frank Cioffi (Hg.). Explanation in the Behavioural Sciences. Cambridge: Cambridge University Press, 1970, p. 329-339.

- Parameter sozialer Strukturen. In: Peter M. Blau (Hg.). Parameter sozialer Strukturen. Opladen: Westdeutscher Verlag. 1978, p. 203-233.

BOHNEN, Alfred. Handlungsprinzipien oder Systemgesetze: über Traditionen und Tendenzen theoretischer Sozialerkenntnis. Tübingen: Mohr Siebeck, 2000.

BREUER, Stefan. Max Webers Herrschaftssoziologie. Frankfurt a.M./New York: Campus, 1991. 
BRÜNTRÜP, Godehard. Das Leib-Seele-Problem: eine Einführung. Stuttgart/Berlin/Köln: Kohlhammer, 2001.

COLEMAN, James S. Grundlagen der Sozialtheorie. Band 1. München: Oldenbourg, 1995.

CUMMINS, Robert. The Nature of Psychological Explanation. Cambridge, MA/London: The MIT Press, 1985.

DIMAGGIO, Paul J.; POWELL, Walter. Das "stahlharte Gehäuse" neu betrachtet: Institutioneller Isomorphismus und kollektive Rationalität in organisationalen Feldern. In: Hans-Peter Müller und Steffen Sigmund (Hg.). Zeitgenössische amerikanische Soziologie. Opladen: Leske + Budrich, 2000, p. 147-173.

ESSER, Hartmut. Soziologie. Allgemeine Grundlagen. Frankfurt a.M./New York: Campus, 1993.

Soziologie. Spezielle Grundlagen, Bd.1. Situationslogik und Handeln, Frankfurt a.M./New York: Campus, 1999.

- Soziologie. Spezielle Grundlagen, Bd.2. Die Konstruktion der Gesellschaft, Frankfurt a.M./New York: Campus, 2000.

. Die Rationalität der Werte. Die Typen des Handelns und das Modell der soziologischen Erklärung. In: Gert Albert, Agathe Bienfait, Steffen Sigmund und Claus Wendt (Hg.). Das Weber-Paradigma: Studien zur Weiterentwicklung von Max Webers forschungsprogramm. Tübingen: Mohr, 2003, p. 153-187

FEIGL, Herbert, 1953: Unity of Science and Unitary Science. In: Herbert Feigl und May Brodbeck (Hg.). Readings in the Philosophy of Science. New York: Appleton - Century Crofts, 1953, p. 382-384.

HEINTZ, Bettina. Emergenz und Reduktion. Neue Perspektiven auf das Mikro-MakroProblem. Kölner Zeitschrift für Soziologie. Sozialpsychologie, v. 56, p. 1-31, 2004.

HELD, Martin; Hans G. Nutzinger (Hg.). Institutionen prägen Menschen: Bausteine zu einer allgemeinen Institutionenökonomik. Frankfurt a.M./New York: Campus, 1999.

; __ Institutionen prägen Menschen - Menschen prägen, Institutionen. In: Martin Held und Hans G. Nutzinger. (Hg.). Bausteine zu einer allgemeinen Institutionenökonomik. Frankfurt a.M./New York: Campus, 1999,p. 7-29.

HOMANS, George C. The Relevance of Psychology to the Explanation of Social Phenomena. In: Robert Borger und Frank Cioffi (Hg.). Explanation in the Behavioural Sciences. Cambridge: Cambridge University Press, 1970, p. 313-329. 
HOYNINGEN-HUENE, Paul. Emergenz, Mikro- und Makrodetermination. In: Weyma Lübbe (Hg.). Kausalität und Zurechnung. Berlin/New York: de Gruyter, 1994, p. 165-195. KAPPELHOF, Peter. Rational Choice, Macht und die korporative Organisation der Gesellschaft. In: Günter Ortmann, Jörg Sydow und Klaus Türk (Hg.). Theorien der Organisation: Die Rückkehr der Gesellschaft. Opladen: Westdeutscher Verlag. 1997, p. 218-258.

KRAUSE, Ullrich. Im Inneren des rationalen Egoisten - Individuelle Akteure und gesellschaftliche Institutionen. In: Martin Held und Hans G. Nutzinger (Hg.). Institutionen prägen Menschen: Bausteine zu einer allgemeinen Institutionenökonomik. Frankfurt a.M./ New York: Campus, 1999, p. 65-84.

LEPSIUS, M. Rainer. Interessen und Ideen. Die Zurechnungsproblematik bei Max Weber. In: M. Rainer Lepsius. Interessen, Ideen und Institutionen. Opladen: Westdeutscher Verlag, 1990, p. 31-43.

LEPSIUS, M. Rainer. Institutionenanalyse und Institutionenpolitik. In: Birgitta Nedelmann (Hg.). Politische Institutionen im Wandel. Sonderheft 35 der KZfSS. Opladen: Westdeutscher Verlag, 1997, p. 392-403.

LEPSIUS, M. Rainer. Eigenart und Potenzial des Weber-Paradigmas. In: Gert Albert, Agathe Bienfait, Steffen Sigmund und Claus Wendt (Hg.). Das Weber-Paradigma: studien zur Weiterentwicklung von Max Webers Forschungsprogramm. Tübingen: Mohr, 2003, p. 32-41.

McCLELLAND, David C.. The Achieving Society. New York: Irvington. Opp, Karl-Dieter, 2004: Die Theorie rationalen Handelns im Vergleich mit alternativen Theorien. In: Manfred Gabriel (Hg.). Paradigmen der akteurszentrierten Soziologie. Wiesbaden: VS-Verlag für Sozialwissenschaften, 1961, p. 43-68.

ROSENBERG, Alexander. Philosophy of social science. Oxford: Clarendon Press, 1988.

SAWYER, Keith. Emergence in Sociology: Contemporary Philosophy of Mind and Some Implications for Sociological Theory. American Journal of Sociology, v. 107, p. 551-585, 2001.

SAWYER, Keith. Durkheim's Dilemma: Toward a Sociology of Emergence. Sociological Theory, n. 20, 2002, p. 227-247.

SCHARPF, Fritz W. Interaktionsformen: akteurzentrierter Institutionalismus in der Politikforschung. Opladen: Leske + Budrich, 2000.

SCHLICHT, Ekkehart. Institutionen prägen Menschen. In: Martin Held und Hans G. Nutzinger (Hg.). Institutionen prägen Menschen. Bausteine zu einer allgemeinen Institutionenökonomik. Frankfurt a.M./New York: Campus, 1999, p. 30-43. 
SCHLUCHTER, Wolfgang. Umbildungen des Charismas: Überlegungen zur Herrschaftssoziologie. In: Religion und lebensführung. Band 2, Frankfurt a.M.: Suhrkamp, 1991, p. 535-554.

Physis und Kultur: Max Weber über Psychophysik. in: Unversöhnte Moderne. Frankfurt a.M.: Suhrkamp, 1996, p. 71-143.

SCHLUCHTER, Wolfgang. Handlungs- und Strukturtheorie nach Max Weber. In: Individualismus, Verantwortungsethik und Vielfalt. Weilerswist: Velbrück, 2000a, p. 86-103.

SCHLUCHTER, Wolfgang. BücherdesJahrhunderts: Max Webers Wirtschaft und Gesellschaft. Grundriß der verstehenden Soziologie. In: Individualismus, Verantwortungsethik und Vielfalt. Weilerswist: Velbrück, 2000b, p. 139-153.

SCHLUCHTER, Wolfgang. Handlung, Ordnung und Kultur. Grundzüge eines weberianischen Forschungsprogramms. In: Gert Albert, Agathe Bienfait, Steffen Sigmund und Claus Wendt (Hg.) Das Weber-Paradigma: studien zur Weiterentwicklung von Max Webers Forschungsprogramm. Tübingen: Mohr, 2003, p. $42-74$.

SCHLUCHTER, Wolfgang. Handlung, Ordnung und Kultur: Studien zu einem Forschungsprogramm im Anschluss an Max Weber. Tübingen: Mohr, 2005.

SCHMID, Michael. Die methodologischen Voraussetzungen des methodologischen Individualismus und dessen Beziehungen zur theoretischen und empirischen Forschung. In: Rationalität und Theoriebildung: Studien zu Karlr. Poppers Methodologie der Sozialwissenschaften. Amsterdam - Atlanta, GA: Rodopi, 1996, p. 56-81.

Kultur und Erkenntnis: Kritische Bemerkungen zu Max Webers Wissenschaftslehre.

Berliner Journal für Soziologie, v. 14, p. 545-560, 2004.

SCHWINN, Thomas. Max Webers Konzeption des Mikro-Makro-Problems. Kölner Zeitschrift für Soziologie und Sozialpsychologie, v. 45, 1993, p. 220-237.

STEPHAN, Achim. Emergenz in Kognitionsfähigen Systemen. In: Michael Pauen und Gerhard Roth (Hg.). Neurowissenschaften und Philosophie. München: Fink, 2002, p. 123-154.

UDEHN, Lars. Methodological Individualism. London/New York: Routledge, 2001.

VANBERG, Viktor. Die zwei Soziologien: Individualismus und Kollektivismus in der Sozialtheorie. Tübingen: Mohr Siebeck, 1975.

WEBER, Max. Wirtschaft und Gesellschaft. 5. Auflage, Tübingen: Mohr (zit. als WuG), 1980. WEBER, Max, 1988: II. Knies und das Irrationalitätsproblem. p. 42-105 in: Gesammelte Aufsätze zur Wissenschaftslehre. Tübingen: Mohr Siebeck. 
WRIGHT, Georg Henrik von. Determinismus in den Geschichts- und Sozialwissenschaften. Ein Entwurf. In: Handlung, Norm und Intention. Berlin/New York: de Gruyter, 1977, p. 131-152.

ZUCKER, Lynne G. The Role of Institutionalization in Cultural Persistence. In: Walter Powell und Paul J. DiMaggio (Hg.). The New Institutionalism in Organizational Analysis. Chicago, IL/London: University of Chicago Press, 1991, p. 83-107.

\section{Moderate methodological holism: a Weberian interpretation of the macro-micro-macro model}

\section{Abstract}

This paper focusses on an unarticulated tendency of Weberian sociology to examine action and order equitable. The methodological position of moderate holism seems to be adequate for the Weber-paradigm. Moderate methodological holism encompasses a holistic ontology and the individualistic macro-micro-macro-model of explanation. In detail it is different of Hartmut Esser's version of this model. On the basis of emergence-theoretical thinking moderate methodological holism is distinguished from three other methodological positions. It is demonstrated that moderate methodological holism is the background for adequate models of explanation of Weber's protestant ethic and his sociology of domination. It is shown that every action-theory in the Weberian sense has a holistic orientation based on the principle "reasons as causes". The holistic orientation should be hold as regards the macro-level of order, too. This version of the Weber-paradigm has a historical and empirical orientation for ontological reasons.

Keywords: Max Weber. Emergence. Holism. Methodological individualism. Explanation. Micromacro problem. 